\title{
Tree - Open Grassland Structure Drives Carbon And Nitrogen Cycling In Mediterranean Wood Pastures of The Iberian Peninsula
}

Mercedes Ibañez ( $\nabla$ mercedes.ibanez@ctfc.cat)

Forest Science and Technology Centre of Catalonia (CTFC) https://orcid.org/0000-0003-0917-6232

\section{Salvador Aljazairi}

University of Lleida (UdL)

María José Leiva

Institute of Agricultural Sciences

Roland A. Werner

Institute of Agricultural Sciences

Jaleh Ghashghaie

Université Paris-Sud, CNRS

Maria Teresa Sebastià

Forest Science and Technology Centre of Catalonia (CTFC)

\section{Research Article}

Keywords: canopy, dehesas, forbs, grasses, isotopes, legumes, plant functional types (PFT).

Posted Date: September 13th, 2021

DOl: https://doi.org/10.21203/rs.3.rs-868173/v1

License: (9) (i) This work is licensed under a Creative Commons Attribution 4.0 International License.

Read Full License 


\section{Abstract}

Purpose: Mediterranean wood pastures are the largest agroforestry system in Europe. Traditional silvopastoral uses shaped these systems into a mosaic of trees and open grassland. However, little is known about how this structure may influence ecosystem carbon $(\mathrm{C})$ and nitrogen $(\mathrm{N})$ dynamics, considering different canopy types and interactions with the herbaceous layer.

Aims: To unravel the canopy effect on $\mathrm{C}$ and $\mathrm{N}$ dynamics (1) under representative canopy types, including traditional Quercus stands and Pinus pinea L. plantations; and (2) in interaction with the herbaceous plant functional types (PFT).

Methods: We analysed $\mathrm{C}$ and $\mathrm{N}$ content and the isotopic natural abundance on soil and plant materials at the open grassland and under the different tree canopies.

Results: Under the canopy, soil $\mathrm{C}$ and $\mathrm{N}$ content, and $\mathrm{N}$ availability for the herbaceous layer increased. The canopy effect performed differences between Quercus and P. pinea plots, as detected on the belowground biomass $\mathrm{C}$ content. Also, the canopy effect was more pronounced with increasing environmental constraints, highlighting the relevance of trees in more restrictive environments. PFT ecophysiological characteristics interacted with tree canopies, as reflected the enhanced efficiency taking-up $\mathrm{N}$, and/or exploiting symbiotic $\mathrm{N}$ of grasses, which was probably one of the causes of their dominancy under the canopy, at higher $\mathrm{N}$ availability.

Conclusion: Changes in the tree coverage and tree species will significantly change ecosystem $\mathrm{C}$ and $\mathrm{N}$ storage and cycling. Therefore, it is highly advisable to preserve a balance between trees and open grassland, and traditional Quercus stands, to keep ecosystem services provisioning.

\section{Introduction}

Mediterranean wood pastures or oak savannahs (called dehesas in Spain and montados in Portugal) are semi-natural savannah-like systems that result from traditional silvo-pastoral uses, in which an herbaceous and an arboreal layer (mostly Quercus species) coexist (Ibañez et al. 2021b). They are one of the largest agroforestry systems in Europe (Eichhorn et al. 2006), covering 3.5 - 4 million ha, mostly along the South West of the Iberian Peninsula (Olea et al. 2005), and are also present in other world regions with Mediterranean climates, mainly in California (Gaman and Firman 2006; Marañón et al. 2009; Huntsinger et al. 2013).

Mediterranean wood pastures have traditionally provided a wide variety of silvo-pastoral goods and services, including production of forage, acorns, timber, and cork. Uses that shaped these systems into a mosaic of trees and open grassland. However, the tree coverage in Mediterranean wood pastures is changing. Traditional silvo-pastoral uses are declining towards intensive farming; plantations of fast-growing trees, mostly Eucalyptus and Pinus species; shrub encroachment due to land abandonment; and there is a worrying lack of tree regeneration (Costa Pérez et al. 2006; Costa et al. 2011). These 
changes are reshaping the tree - open grassland mosaic, with the consequent implications that this may have on ecosystem functioning, and specifically on carbon (C) and nitrogen $(\mathrm{N})$ cycling and storage.

To this regard, the natural abundance of $\mathrm{C}$ and $\mathrm{N}$ isotopes - here given as $\delta^{13} \mathrm{C}$ and $\delta^{15} \mathrm{~N}$ values - can be used as a proxy to assess $\mathrm{C}$ and $\mathrm{N}$ acquisition and processing (Dawson et al. 2002; Ferrio et al. 2005; Kahmen and Buchmann 2007). Discrimination against ${ }^{13} \mathrm{C}$ in $\mathrm{C}_{3}$ plants is directly linked to photosynthetic net $\mathrm{CO}_{2}$ assimilation and stomatal conductance, increasing discrimination against ${ }^{13} \mathrm{C}$ with increasing stomatal conductance (Farquhar et al. 1989). Variations in $\delta^{13} \mathrm{C}$ are then controlled by physiological and environmental factors (Farquhar et al. 1982, 1989), and $\delta^{13} \mathrm{C}$ of plant organic matter has been identified as a useful tool to assess $\mathrm{CO}_{2}$ and water exchange relationships (Ehleringer et al. 1990). Thus, tree canopies directly influence light availability, which in turn controls photosynthetic activity and C cycling (Bonafini et al. 2013). The light reduction below the canopy generally increases stomatal conductance, making possible more discrimination against ${ }^{13} \mathrm{C}$, and generating organic matter depleted in ${ }^{13} \mathrm{C}$ (van der Merwe and Medina 1991; Buchmann et al. 1997; Della Coletta et al. 2009; Bonafini et al. 2013).

On the other hand, $\delta^{15} \mathrm{~N}$ in the above and belowground biomass will depend mostly on the amount and the type of $\mathrm{N}$ sources, $\mathrm{N}$ cycling steps, and the microbial community (Robinson 2001; Dawson et al. 2002). Particularly with regard to $\mathrm{N}$ availability, plants tend to fractionate against ${ }^{15} \mathrm{~N}$ at high $\mathrm{N}$ availability, meaning that the remaining source will be more ${ }^{15} \mathrm{~N}$ enriched, while the biomass exploiting the $\mathrm{N}$ source will be ${ }^{15} \mathrm{~N}$ depleted (Yoneyama et al. 2001). On the contrary, at limiting $\mathrm{N}$ conditions there will be very low ${ }^{15} \mathrm{~N}$ discrimination, and the exploiting biomass will have a $\delta^{15} \mathrm{~N}$ similar to the source (Evans et al. 1996). Also, at low $\mathrm{N}$ availability, plants will be more dependent on symbiotic $\mathrm{N}$ fixed from atmospheric $\mathrm{N}_{2}$ by bacteria (Evans 2001; Santi et al. 2013).

Thus, a "canopy effect" on the $\mathrm{C}$ and $\mathrm{N}$ content and the natural isotopic composition $\left(\delta^{13} \mathrm{C}\right.$ and $\left.\delta^{15} \mathrm{~N}\right)$ of the different ecosystem compartments is expected. However, still little is known about how such "canopy effect" may differ among canopy types of Iberian wood pastures. Even less is known about how the different plant functional types (PFT) of the herbaceous layer may differ in their response to the presence/absence of tree canopies in terms of $\mathrm{C}$ and $\mathrm{N}$ cycling. Indeed, the herbaceous layer of Iberian wood pastures is highly diverse (Marañon 1985), and the two microhabitats (open grassland and under the canopy canopy) are known to differ in terms of plant specific and functional diversity and composition. Grasses being dominant under the canopy, while legume forbs (hereafter "legumes") and non-legume forbs (hereafter "forbs") are limited in their growth under the canopy (Olsvig-Whittaker et al. 1992; Gea-Izquierdo et al. 2009; Marañón et al. 2009; Lopez-Carrasco et al. 2015; Ibañez 2019).

Also, these PFT are known to differ in their $\mathrm{N}$ and light (and therefore $\mathrm{CO}_{2}$ ) use and acquisition strategies (Tilman et al. 1997; Symstad 2000; Lavorel et al. 2007; Sebastià 2007; Ibañez et al. 2020). Legumes being widely known for their capacity to fix symbiotic $N$, which may result in higher rates of net $\mathrm{CO}_{2}$ uptake (Ibañez et al. 2020, 2021b, a); while grasses have erect and high-density leaves that 
ensure good light penetration (Craine et al. 2001). Whereby a differential $\mathrm{C}$ and $\mathrm{N}$ cycling response to tree canopies among those PFT is expected.

Hence, in the present study we specifically aim at assessing such canopy effect on the different ecosystem compartments, including the soil and the above and belowground biomass. Specifically aiming at unravelling the canopy effect (1) under representative canopy types of Iberian wood pastures, considering traditional Quercus stands and Pinus pinea L. plantations, a common tree plantation replacing traditional canopies (Costa Pérez et al. 2006); and (2) in interaction with the PFT of the herbaceous layer.

\section{Material And Methods}

\subsection{Study sites and sampling design}

Study sites were the same as reported in Ibañez et al. (2021), distributed in two locations in the South-West of the Iberian Peninsula: Doñana Natural Park (DN, 37 $15^{\prime} 34^{\prime \prime} \mathrm{N}, 6^{\circ} 19^{\prime} 55^{\prime \prime}$ W, 30 m a. s. I.) and Sierra Morena mountains (SM, 37 39' 50" N, $5^{\circ} 56^{\prime} 20^{\prime \prime}$ W, $296 \mathrm{~m}$ a. s. I.). Both locations have Mediterranean climate regime with warm, dry summers, and mild winters (Peel et al. 2007). However, SM is slightly cooler and wetter than DN, with a mean annual temperature in $\mathrm{SM}$ of $16.8^{\circ} \mathrm{C}$ and in $\mathrm{DN}$ of $18.1^{\circ} \mathrm{C}$, and a mean annual precipitation in SM of $648 \mathrm{~mm}$ and in DN of $543 \mathrm{~mm}$. Grasslands in both locations are dominated by herbaceous annual species, including grasses, forbs, and legumes. Both locations are extensively grazed at similar stocking rates: $\mathrm{DN}$ grazed by goat and cattle ( 0.40 livestock units (LSU) ha $\left.{ }^{-1}\right)$, and SM by cattle and Iberian pigs (0.36 $\mathrm{LSU} \mathrm{ha}^{-1}$ ).

Study plots were selected according to their tree composition, with representative canopy types of Iberian wood pastures (Costa Pérez et al. 2006). One pure Q. ilex stand, in the SM location (SM-ilex), and one pure $Q$. suber stand in the DN location (DN-suber), both the most abundant stands in the Iberian Peninsula; one $Q$. ilex and $Q$. suber mixed stand (DN-mixed), the next most abundant stand; and a pure Pinus pinea L. stand (DN-pinea), a common tree plantation replacing traditional canopies (Costa Pérez et al. 2006).

Field work was carried out in spring (2016//04/05 - 2016/04/10), coinciding with the most productive moment of the system. Study treatments were therefore established according to plot (SM-ilex, DN-mixed, DN-suber and DN-pinea), and canopy (open grassland, OG, and under the canopy, UC). At each treatment level we sampled 4 replicates, resulting in 40 sampling points, sampling aboveground biomass (Section 2.2), belowground biomass and soil (Section 2.3). In the DN-mixed plot we discriminated between both Quercus species ( $Q$. suber and $Q$. ilex) to establish sampling points. However, we performed preliminary comparative analysis in the $\mathrm{DN}$-mixed plot on environmental and vegetation characteristics under the canopy of both Quercus species and no relevant differences between Quercus species were found. DN-mixed results are then always presented combining both tree species. 


\subsection{Aboveground biomass sampling}

At each sampling point we sampled same dominant species of each PFT including grasses (Bromus hordeaceus L. and Hordeum vulgare L.); forbs (Calendula arvensis L., Chamamelum mixtum L, Crepis capillaris L., Erodium moschatum L., and Geranium molle L.); and legumes (Ornithopus sativus Brot. and Trifolium subterraneum L.). Also, PFT composition from the same study plots (Ibañez et al. 2021b) was used to interpret and discuss our results.

\subsection{Soil and belowground biomass sampling}

Two soil cores of $9 \mathrm{~cm}^{2}$ surface and $0-10 \mathrm{~cm}$ depth were extracted at each sampling point. In the laboratory, one of the cores was processed for soil analysis, and the second core washed and filtered with a $0.2 \mathrm{~mm}$ pore size strainer to obtain belowground biomass (BGB).

\subsection{Determination of carbon and nitrogen content and isotopic natural abundance}

All collected samples, including soil, BGB, and the herbaceous layer sorted by PFT - grasses, forbs, and legumes -, were oven dried at $60^{\circ} \mathrm{C}$ until constant weight, powdered with a ball mill (MM200, Retsch, Asturias, Spain) and tin capsuled (Courtage Analyse Service, Mont Saint-Aignan, France). For determining $\mathrm{C}$ content and $\delta^{13} \mathrm{C}$ in all our samples, except soils, we used glutamic acid and acetanilide laboratory standards, both calibrated with USGS40 international reference material. For determining the percentage of $\mathrm{N}$ and $\delta^{15} \mathrm{~N}$ an additional standard was also used $\left(\mathrm{N}_{1}\right)$, calibrated using IAEA-N $\mathrm{N}_{1}$. Samples were prepared in the Institut de Biologie des Plantes (http://www.ips2.u-psud.fr). Afterwards, samples were analysed in the Isolab of the Grassland Sciences group at ETH Zurich (http://www.gl.ethz.ch/), with a Flash EA 1112 Series elemental analyser (Finnigan MAT, Bremen, Germany), coupled to a Delta ${ }^{\text {plus XP }}$ isotope ratio mass spectrometer (Finnigan MAT, Bremen, Germany) via a 6-port valve (Brooks et al. 2003) and a ConFlo III interface (Werner et al. 1999).

For determining $\mathrm{C}$ content and $\delta^{13} \mathrm{C}$ in the soil, we used acetanilide and caffeine as standards, both calibrated using glutamic acid from IAEA, USGS40, and NBS-22. In determining the percentage of N and $\delta^{15} \mathrm{~N}$ in the soil, tyrosine was also used as standard calibrated using IAEA-N $\mathrm{N}_{1}$. Soil samples were prepared and analysed in the Isolab of the Grassland Sciences group at ETH Zurich, as described above.

Isotopic composition $\left(\delta^{13} \mathrm{C}\right.$ and $\left.\delta^{15} \mathrm{~N}\right)$ were both calculated as deviation of the isotope ratio $\left(\mathrm{R}={ }^{13} \mathrm{C} /{ }^{12} \mathrm{C}\right.$ or $\left.\mathrm{R}={ }^{15} \mathrm{~N} /{ }^{14} \mathrm{~N}\right)$ of the samples from the ratio of the corresponding international standard $\left(\delta=\left(\mathrm{R}_{\text {sample }} /\right.\right.$ $\left.R_{\text {standard }}\right)-1$ ), VPDB for $\delta^{13} \mathrm{C}$, and air- $\mathrm{N}_{2}$ for $\delta^{15} \mathrm{~N}$ (Coplen 2011). 


\subsection{Data analysis}

All data analyses were performed using R software ( $R$ Core Team 2019). We ran linear models on $C$ and $N$ content and isotopic composition $\left(\delta^{13} \mathrm{C}, \delta^{15} \mathrm{~N}\right)$ of each ecosystem compartment as function of plot (SM-ilex, DN-mixed, DN-suber, DN-pinea), and canopy (OG, UC). Final models were selected by a stepwise procedure based on the Akaike information criterion (AIC), using the stepAIC function, MASS package (Venables and Ripley 2002). Linear models were also applied to explore the relationships between $\mathrm{C}$ and $\mathrm{N}$ dynamics within or between ecosystem compartments when applicable. Finally, we assessed differences among PFT on the $\mathrm{C}$ and $\mathrm{N}$ content and isotopic composition $\left(\delta^{13} \mathrm{C}, \delta^{15} \mathrm{~N}\right)$ by one way ANOVAs, and tukey post-hoc tests, using the HSD.test function of the agricolae package (Mendiburu 2017). Only significant models $(p<0.05)$ are presented and discussed, selecting the most explanatory and parsimonious ones.

\section{Results}

Both soil $\mathrm{C}$ and $\mathrm{N}$ contents were consistently higher under the canopy than in the open grassland in all the study plots (canopy effect, Table 1 and Fig. $1 a-b)$. Soil $C$ and $N$ were positively correlated $\left(R^{2} 0.9, p<\right.$ 0.001 , Fig. 1C). At the same time, the environment under the canopy, with enhanced soil $\mathrm{N}$ content, favoured ${ }^{15} \mathrm{~N}$ fractionation by the BGB (decreasing $\delta^{15} \mathrm{~N}$, Fig. 2).

Tree canopies influenced the $\mathrm{C}$ content in the BGB, but with differences between Quercus species and $P$. pinea dominated plots (Fig. 3). BGB presented higher $C$ content under the canopy than in the open grassland in all the plots dominated by Quercus species (SM-ilex, DN-mixed, DN-suber, Fig. 3); while in the $P$. pinea dominated plot the $\mathrm{C}$ content in the BGB decreased under the canopy compared to the open grassland (DN-pinea $x$ canopy effect, Table 2 and Fig. 3).

Among PFT of the herbaceous layer, forbs also responded to tree canopies, but with some differences between locations (DN vs. SM). Forbs presented more ${ }^{13} \mathrm{C}$ depleted tissues under the canopy than in the open grassland in all DN plots, especially in DN-mixed and DN-pinea plots (DN-mixed and DN-pinea effect, Table 3); while such effect was not noticeable in the SM-ilex plot (Table 3 and Fig. 4a). Similarly, the $\mathrm{N}$ content in forbs increased under the canopy in all DN plots, especially noticeable in the DN-mixed and DN-pinea plots (DN-mixed $x$ canopy and DN-pinea $x$ canopy effect, Table 3 ); while the $\mathrm{N}$ content in forbs in the SM-ilex plot did not show any difference between under the canopy and the open grassland (Table 3 and Fig. 4b).

In addition, legumes presented the highest $\mathrm{N}$ content (Fig. 5a), as well as the most ${ }^{15} \mathrm{~N}$ (Fig. $5 \mathrm{~b}$ ), and ${ }^{13} \mathrm{C}$ (Fig. 5c) depleted tissues among the PFT of the herbaceous layer. Conversely, when comparing grasses and forbs, grasses had generally higher $\mathrm{N}$ content than forbs (Fig. 6a), and lower values of $\delta^{15} \mathrm{~N}$ (Fig. 6b).

\section{Discussion}




\subsection{The canopy effect under representative canopy types of Iberian wood pastures}

Intra-plot soil $\mathrm{C}$ and $\mathrm{N}$ dynamics were strongly driven by the presence of trees, as shows the higher soil $\mathrm{C}$ and $\mathrm{N}$ content under the canopy compared to the open grassland (Fig. 1 and Table 1). This was most likely related to a higher input of litter from the trees; which in addition was probably more recalcitrant than that from the herbaceous species, increasing the organic matter accumulation and soil $\mathrm{C}$ and $\mathrm{N}$ stocks under tree canopies (Dahlgren et al. 1997; Howlett et al. 2011; Gómez-Rey et al. 2013; PulidoFernández et al. 2013; Andivia et al. 2015). At the same time, the environment under the canopies favoured the ${ }^{15} \mathrm{~N}$ fractionation by plants, as shown by the lower $\delta^{15} \mathrm{~N}$ in the BGB compared to the open grassland. (Fig. 2). This higher ${ }^{15} \mathrm{~N}$ fractionation by plants might be related to a higher soil $\mathrm{N}$ availability under canopies than in the open grassland (Fig. 2), conditions that can allow a higher ${ }^{15} \mathrm{~N}$ fractionation (Dawson et al. 2002; Kalcsits et al. 2014). However, the type of $\mathrm{N}$ sources and $\mathrm{N}$ cycling steps (Robinson 2001; Dawson et al. 2002), as well as the microbial community (Handley and Raven 1992; Unkovich 2013; Liu et al. 2017), can also leave an imprint the ${ }^{15} \mathrm{~N}$ composition

Moreover, the canopy had a differential effect depending on the tree species that dominated the plot. This was detected on the $\mathrm{C}$ content in the $\mathrm{BGB}$, as showed the higher $\mathrm{C}$ content under the canopy than in the open grassland in all the plots dominated by Quercus species (SM-ilex, DN-suber and DN-mixed), while the $P$. pinea dominated plot (DN-pinea) presented the opposite pattern (Fig. 3). Fact that suggests us a differential magnitude of the drivers in each case. First, the higher $C$ content in the BGB under the canopies detected in the plots dominated by Quercus species may be related to the presence of the tree itself. Although BGB samples were quite superficial $(0-10 \mathrm{~cm})$, tree fine roots may increase the overall $C$ content in the BGB (Kumar et al. 2010). Second, PFT composition of the herbaceous layer differed between under the canopy and the open grassland - therefore most likely there was a change in the BGB composition -, with legumes mostly appearing in the open grassland, while grasses were dominant under the canopy (Ibañez et al. 2021b). Thus, legumes have higher root respiration rates, lower $\mathrm{C}$ storage, and lower $\mathrm{C} / \mathrm{N}$ ratio than forbs and grasses (Warembourg et al. 2003), properties that could result in a lower $\mathrm{C}$ content in the BGB in the open grassland compared to under the canopy (Fig. 3).

Conversely, the lower $\mathrm{C}$ content in the BGB detected in the DN-pinea plot under the canopy compared to the open grassland (Table 2 and Fig. 3 ) could be driven by the low $\mathrm{N}$ availability. The DN-pinea plot in the open grassland presented the lowest soil $\mathrm{N}$ content and the BGB tissue with the highest ${ }^{15} \mathrm{~N}$ enrichment (Fig. 2), suggesting that $\mathrm{N}$ availability for plants could be here quite low and ${ }^{15} \mathrm{~N}$ fractionation could be more restricted. Conditions that may increase root $C$ content (van Diest 1987) to get a limiting resource (Ågren and Ingestad 1987; Gargallo-Garriga et al. 2014). On the other hand, the BGB under $P$. pinea canopy had the most ${ }^{15} \mathrm{~N}$ enriched tissues, even though soil $\mathrm{N}$ content was not the lowest one under the canopy (Fig. 2); and $\delta^{15} \mathrm{~N}$ differences between both microenvironments (open grassland and under the tree) were much lower for $P$. pinea than for Quercus species (Fig. 2). Overall, these suggesting that $\mathrm{N}$ availability for plants in the $P$. pinea plot might be more limited than that on plots dominated by 
Quercus species. The litter characteristics of $P$. pinea is known for its allelopathic properties (ValeraBurgos et al. 2012) and poor in N content, lower than litter of Quercus species (Fioretto et al. 2008; Sheffer et al. 2015). Facts that may be driving these differences in terms of $\mathrm{N}$ availability. Nevertheless, we recommend further research on the effect of tree litter on soil-belowground biomass interactions to clarify this point.

The canopy effect was also dependent on the location (DN vs. SM), as showed the almost neutral canopy effect found on the $\delta^{13} \mathrm{C}$ and the $\mathrm{N}$ content of forbs, in contrast to the strong canopy effect detected in all DN plots (Fig. 4). This results suggests a coupling between $C$ and $N$ cycling (Aljazairi et al. 2014), and interestingly agree with the net ecosystem $\mathrm{CO}_{2}$ exchange patterns reported by lbañez et al. (2021) from the same study plots. The authors reported that: (a) in the $\mathrm{SM}$-ilex plot $\mathrm{CO}_{2}$ exchange was dominated by net $\mathrm{CO}_{2}$ uptake both under the canopy and in the open grassland; while (b) in all DN plots there was net $\mathrm{CO}_{2}$ uptake in the open grassland, but $\mathrm{CO}_{2}$ emissions under the canopy. These results combined with our $\delta^{13} \mathrm{C}$ values suggest that the stomatal conductance is similar between both microenvironments in SM, therefore similar ${ }^{13} \mathrm{C}$ discrimination rates are possible, in opposition to the strong differences found in DN. Similarly, the differential canopy effect found on the $\mathrm{N}$ content of forbs, suggests that also in terms of $\mathrm{N}$ availability, both microenvironments in the SM-ilex did not differ much, in contrast to the pronounced differences found in DN. Eventually, these facts highlighting the relevance of trees as drivers of ecosystem fertility and buffers of extreme conditions, especially in more constrained environments, as is DN vs. SM.

\subsection{Interactions among tree canopies and plant functional types of the herbaceous layer}

PFT of the herbaceous layer (forbs, grasses, and legumes) were exploiting $\mathrm{C}$ and $\mathrm{N}$ resources in particular ways under trees' influence, and this in turn driving ecosystem $\mathrm{C}$ and $\mathrm{N}$ cycling. As expected, legumes highlighted in terms of $\mathrm{N}$ and $\mathrm{C}$ acquisition and use (Fig. 5). Legumes are known for their higher leaf $\mathrm{N}$ content (Fig. 5a), coming mostly from symbiotically fixed sources (Fig. 5a), and generally present a low leaf mass/area ratio and thickness. These traits result in a shorter internal diffusion pathway from stomata to chloroplasts, and generate greater $\mathrm{CO}_{2}$ conductance and consequently greater $\mathrm{CO}_{2}$ supply for carboxylation ( $\mathrm{Li}$ et al. 2016). The greater $\mathrm{CO}_{2}$ supply leads to both higher root respiration (Warembourg et al. 2003) and leaf $\mathrm{CO}_{2}$ exchange rates ( $\mathrm{Li}$ et al. 2016), and eventually more depleted ${ }^{13} \mathrm{C}$ tissues than those of grasses and forbs (more negative $\delta^{13} \mathrm{C}$, Fig. $5 \mathrm{c}$ ).

However, although legumes perform higher $\mathrm{CO}_{2}$ exchange rates than grasses and forbs (Ibañez et al. 2020), the environment under the canopy did not favour their abundance (Ibañez et al. 2021b). Legumes are limited for their high light demand (Gea-Izquierdo et al. 2009; Marañón et al. 2009; Lopez-Carrasco et al. 2015), and competition with species that are favoured under higher $\mathrm{N}$ availability, as is the case of grasses. Indeed, the differences in the $\mathrm{N}$ acquisition and use detected between forbs and grasses (Fig. 6 ) 
is suggesting such competitive advantage for grasses. The higher $\mathrm{N}$ content (Fig. 6a) and the generally lower $\delta^{15} \mathrm{~N}$ (Fig. $6 \mathrm{~b}$ ) in grasses compared to forbs, suggests that grasses may be highly efficient takingup $\mathrm{N}$ and/or exploiting symbiotic $\mathrm{N}$ sources (Yoneyama et al. 2001).

Thus, N-transfer between grasses and legumes (source of symbiotic N, Fig. $5 \mathrm{~b}$ ) has been described to be more efficient than between legumes and forbs (Pirhofer-Walzl et al. 2012). Also, grasses usually have fibrous roots (Weaver 1958; Schenk and Jackson 2002; Pirhofer-Walzl et al. 2012), trait that may facilitate higher $\mathrm{N}$ absorption from the most superficial soil layers, and from symbiotically fixed $\mathrm{N}$; while forbs have generally taproots that are not so efficient to this effect (Pirhofer-Walzl et al. 2012). Overall, grasses being very competitive at high $\mathrm{N}$ availability (Song et al. 2011), via increasing their biomass at the expense of forbs and legumes, which is probably one of the causes of their dominance under the canopy, where there is higher soil $\mathrm{N}$ (Fig. 1b).

\section{Conclusion}

Changes in the tree coverage and tree species may cause profound changes on $\mathrm{C}$ and $\mathrm{N}$ dynamics in Mediterranean wood pastures. Overall, trees acted as islands of fertility, as reflected by the higher soil $\mathrm{N}$ and $\mathrm{C}$ content, and the higher rates of ${ }^{15} \mathrm{~N}$ discrimination by the BGB under the canopy compared to the open grassland, which indicates higher $\mathrm{N}$ availability for plants. However, such canopy effect presented some differences related to the dominant tree species and local conditions. In terms of tree species, $\mathrm{N}$ availability in the $P$. pinea dominated plot seemed to be lower than that in Quercus species dominated plots, and this in turn changed the canopy effect over the C content of the BGB. Second, in terms of local conditions, the canopy effect on $\mathrm{C}$ and $\mathrm{N}$ cycling was generally more pronounced with increasing environmental constraints (as is DN vs. SM), highlighting the relevance of trees as drivers of ecosystem fertility and $\mathrm{C}$ and $\mathrm{N}$ relationships, especially in more constrained environments. On the other hand, each PFT drove ecosystem $\mathrm{C}$ and $\mathrm{N}$ cycling in particular ways, as for instance reflected the higher $\mathrm{N}$ content

and the generally lower $\delta^{15} \mathrm{~N}$ of grasses compared to forbs, which suggests that grasses were highly competitive under the canopy, where there was higher soil $\mathrm{N}$ content. Our results indicate that it is highly advisable to preserve a balance between trees and open grassland spaces, as well as traditional Quercus stands; to keep ecosystem fertility and the structure and composition of the herbaceous layer, in order to guarantee ecosystem services provisioning and preservation of Mediterranean wood pastures.

\section{Declarations}

\section{Funding}

This work was funded by the Spanish Science Foundation FECYT-MINECO: BIOGEI (GL201349142-C2-1-

R) and IMAGINE (CGL2017-85490-R) projects and supported by a FPI fellowship to M. I. (BES2014069243). 


\section{Competing interests}

The authors declare that they have no competing interests.

\section{Acknowledgements}

This work was funded by the Spanish Science Foundation FECYT-MINECO: BIOGEI (GL201349142-C2-1R) and IMAGINE (CGL2017-85490-R) projects and supported by a FPI fellowship to Mercedes Ibañez (BES2014-069243). Thanks to all the colleagues who collaborated in laboratory and fieldwork tasks: Antonio Rodríguez, Miquel Sala, Helena Sarri and Gianluca Segalina. Our special thanks to Dehesa de Gato S. L. state and Doñana Research Coordination Office for their support and facilities.

\section{References}

1. Ågren GI, Ingestad T (1987) Root: shoot ratio as a balance between nitrogen productivity and photosynthesis. Plant Cell Environ 10:579-586. https://doi.org/10.1111/1365-3040.ep11604105

2. Aljazairi S, Arias C, Sánchez E et al (2014) Effects of pre-industrial, current and future $\left[\mathrm{CO}_{2}\right]$ in traditional and modern wheat genotypes. J Plant Physiol 171:1654-1663. https://doi.org/10.1016/j.jplph.2014.07.019

3. Andivia E, Fernández M, Alejano R, Vázquez-Piqué J (2015) Tree patch distribution drives spatial heterogeneity of soil traits in cork oak woodlands. Ann For Sci 549-559. https://doi.org/10.1007/s13595-015-0475-8

4. Bonafini M, Pellegrini M, Ditchfield P, Pollard AM (2013) Investigation of the "canopy effect" in the isotope ecology of temperate woodlands. J Archaeol Sci 40:3926-3935. https://doi.org/10.1016/j.jas.2013.03.028

5. Brooks PD, Geilmann H, Werner RA, Brand WA (2003) Improved precision of coupled $\delta^{13} \mathrm{C}$ and $\delta^{15} \mathrm{~N}$ measurements from single samples using an elemental analyzer/isotope ratio mass spectrometer combination with a post-column six-port valve and selective $\mathrm{CO}_{2}$ trapping; improved ha. Rapid Commun Mass Spectrom 17:1924-1926. https://doi.org/10.1002/rcm.1134

6. Buchmann N, Kao WY, Ehleringer J (1997) Influence of stand structure on carbon-13 of vegetation, soils, and canopy air within deciduous and evergreen forests in Utah, United States. Oecologia 110:109-119. https://doi.org/10.1007/s004420050139

7. Coplen TB (2011) Guidelines and recommended terms for expression of stable-isotope-ratio and gasratio measurement results. Rapid Commun Mass Spectrom 25:2538-2560. https://doi.org/10.1002/rcm.5129

8. Costa A, Madeira M, Lima Santos J, Oliveira Â (2011) Change and dynamics in Mediterranean evergreen oak woodlands landscapes of Southwestern Iberian Peninsula. Landsc Urban Plan 102:164-176. https://doi.org/10.1016/j.landurbplan.2011.04.002 
9. Costa Pérez JC, Martín Vicente Á, Fernández Alés R et al (2006) Dehesas de Andalucía. Caracterización ambiental, Sevilla

10. Craine JM, Froehle J, Tilman DG et al (2001) The relationships among root and leaf traits of 76 grassland species and relative abundance along fertility and disturbance gradients. Oikos 93:274285. https://doi.org/10.1034/j.1600-0706.2001.930210.x

11. Dahlgren RA, Singer MJ, Huang X (1997) Oak tree and grazing impacts on soil properties and nutrients in a california oak woodland. Biogeochemistry 39:45-64. https://doi.org/10.1023/A:1005812621312

12. Dawson TE, Mambelli S, Plamboeck AH et al (2002) Stable Isotopes in Plant Ecology. Annu Rev Ecol Syst 33:507-559. https://doi.org/10.1146/annurev.ecolsys.33.020602.095451

13. Della Coletta L, Bielefeld Nardoto G, Ribeiro Latansio-Aidar S, Ribeiro da Rocha H (2009) Isotopic view of vegetation and carbon and nitrogen cycles in a cerrado ecosystem, southeastern Brazil. Sci Agric 66:467-475. https://doi.org/10.1590/S0103-90162009000400006

14. Ehleringer J, White J, Johnson DA, Brick M (1990) Carbon isotope discrimination, photosynthetic gas exchange, and transpiration efficiency in beans and range grasses. Acta Oecol 11:611-625

15. Eichhorn MP, Paris P, Herzog F et al (2006) Silvoarable systems in Europe - past, present and future prospects. Agrofor Syst 67:29-50. https://doi.org/10.1007/s10457-005-1111-7

16. Evans RD (2001) Physiological mechanisms influencing plant nitrogen isotope composition. Trends Plant Sci 6:121-126. https://doi.org/10.1016/S1360-1385(01)01889-1

17. Evans RD, Bloom AJ, Sukrapanna SS, Ehleringer JR (1996) Nitrogen isotope composition of tomato (Lycopersicon esculentum Mill. cv. T-5) grown under ammonium or nitrate nutrition. Plant Cell Environ 19:1317-1323. https://doi.org/10.1111/j.1365-3040.1996.tb00010.x

18. Farquhar GD, Ehleringer JR, Hubick KT (1989) Carbon Isotope Discrimination and Photosynthesis. Annu Rev Plant Physiol Plant Mol Biol 40:503-537. https://doi.org/10.1146/annurev.pp.40.060189.002443

19. Farquhar GD, O'Leary MH, Berry JA (1982) On the relationship between carbon isotope discrimination and the intercellular carbon dioxide concentration in leaves. Aust J Plant Physiol 9:121-137. https://doi.org/10.1071/PP9820121

20. Ferrio P, Resco V, Williams D et al (2005) Stable isotopes in arid and semi-arid forest systems. Investig Agrar Sist y Recur For 14:371-382. https://doi.org/10.5424/srf/2005143-00929

21. Fioretto A, Papa S, Pellegrino A, Fuggi A (2008) Leaf litter decomposition dynamics in Mediteranean area. In: Tian-Xiao L (ed) Soil Ecology Research Developements. Nova Science Publishers, Inc., New York

22. Gaman T, Firman J (2006) Oaks 2040. The Status and Future of Oaks in California, Oakland

23. Gargallo-Garriga A, Sardans J, Pérez-Trujillo M et al (2014) Opposite metabolic responses of shoots and roots to drought. Sci Rep 4:1-7. https://doi.org/10.1038/srep06829 
24. Gea-Izquierdo G, Montero G, Cañellas I (2009) Changes in limiting resources determine spatiotemporal variability in tree-grass interactions. Agrofor Syst 76:375-387.

https://doi.org/10.1007/s10457-009-9211-4

25. Gómez-Rey MX, Madeira M, Gonzalez-Prieto SJ, Coutinho J (2013) Soil C and N dynamics in a Mediterranean oak woodland with shrub encroachment. Plant Soil 371:339-354. https://doi.org/10.1007/s11104-013-1695-z

26. Handley LL, Raven JA (1992) The use of natural abundance of nitrogen isotopes in plant physiology and ecology. Plant Cell Environ 15:965-985. https://doi.org/10.1111/j.1365-3040.1992.tb01650.x

27. Howlett DS, Moreno G, Mosquera Losada MR et al (2011) Soil carbon storage as influenced by tree cover in the Dehesa cork oak silvopasture of central-western Spain. J Environ Monit 13:1897-1904. https://doi.org/10.1039/c1em10059a

28. Huntsinger L, Campos P, Starrs PF et al (2013) Working Landscapes of the Spanish Dehesa and California Oak Woodlands: An Introduction. In: Campos P, Huntsinger L, Oviedo JL, et al. (eds) Mediterranean Oak Woodland Working Landscapes. Dehesas of Spain and Ranchlands of California. Springer New York, pp 3-23

29. Ibañez M (2019) Vegetation drives greenhouse gas exchange, and carbon and nitrogen cycling in grassland ecosystems. Ph.D. thesis, HBJ Department, Universitat de Lleida, Lleida, Spain, 226 pp

30. Ibañez M, Altimir N, Ribas À et al (2020) Phenology and plant functional type dominance drive $\mathrm{CO}_{2}$ exchange in seminatural grasslands in the Pyrenees. J Agric Sci 1-12. https://doi.org/10.1017/S0021859620000179

31. Ibañez M, Altimir N, Ribas À et al (2021a) Cereal-legume mixtures increase net $\mathrm{CO} 2$ uptake in a forage crop system in the Eastern Pyrenees. F Crop Res 272:108262.

https://doi.org/10.1016/j.fcr.2021.108262

32. Ibañez M, Leiva MJ, Chocarro $C$ et al (2021b) Tree-Open Grassland Structure and Composition Drive Greenhouse Gas Exchange in Holm Oak Meadows of the Iberian Peninsula. Agronomy 11:50:1-16. https://doi.org/10.3390/agronomy 11010050

33. Kahmen A, Buchmann N (2007) Addressing the Functional Value of Biodiversity for Ecosystem Functioning Using Stable Isotopes. In: Terrestrial Ecology. pp 345-359

34. Kalcsits LA, Buschhaus HA, Guy RD (2014) Nitrogen isotope discrimination as an integrated measure of nitrogen fluxes, assimilation and allocation in plants. Physiol Plant 151:293-304. https://doi.org/10.1111/ppl.12167

35. Kumar S, Udawatta RP, Anderson SH (2010) Root length density and carbon content of agroforestry and grass buffers under grazed pasture systems in a Hapludalf. Agrofor Syst 80:85-96. https://doi.org/10.1007/s10457-010-9312-0

36. Lavorel S, Díaz S, Cornelissen JHC et al (2007) Plant Functional Types: Are We Getting Any Closer to the Holy Grail? In: Canadel JG, Pataki DE, Pitelka LF (eds) Terrestrial Ecosystems in a Changing World. Global Change - The IGBP Series. Springer Berlin Heidelberg, Berlin, pp 149-164 
37. Li J, Wang G, Zhang R, Li L (2016) A negative relationship between foliar carbon isotope composition and mass-based nitrogen concentration on the eastern slope of mount gongga, China. PLoS One 11:1-14. https://doi.org/10.1371/journal.pone.0166958

38. Liu H, Carvalhais LC, Crawford M et al (2017) Inner Plant Values: Diversity, Colonization and Benefits from Endophytic Bacteria. Front Microbiol 8:1-17. https://doi.org/10.3389/fmicb.2017.02552

39. Lopez-Carrasco C, Lopez-Sanchez A, San Miguel A, Roig S (2015) The effect of tree cover on the biomass and diversity of the herbaceous layer in a Mediterranean dehesa. Grass Forage Sci 70:639650. https://doi.org/10.1111/gfs.12161

40. Marañon A (1985) Diversidad floristica y heterogenidad ambiental en una dehesa de Sierra Morena. An Edafol Agro- biol 44:1183-1197

41. Marañón T, Pugnaire Fl, Callaway RM (2009) Mediterranean-climate oak savannas: The interplay between abiotic environment and species interactions. Web Ecol 9:30-43. https://doi.org/10.5194/we-9-30-2009

42. Mendiburu F (2017) agricolae: Statistical Procedures for Agricultural Research. R Packag version 12 - 8 https//CRANR-project.org/package = agricolae

43. Olea L, López-Bellido RJ, Poblaciones M (2005) Europe types of silvopastoral systems in the Mediterranean area: Dehesa. In: Mosquera-Losada MR, Rigueiro-Rodríguez A, McAdam J (eds) Silvopastoralism and sustainable land management. Proceedings of an international congress on silvopastoralism and sustainable management held in Lugo, Spain, April 2004. pp 30-35

44. Olsvig-Whittaker LS, Naveh Z, Giskin M, Nevo E (1992) Microsite differentiation in a Mediterranean oak savanna. J Veg Sci 3:209-216. https://doi.org/10.2307/3235681

45. Peel MC, Finlayson BL, McMahon TA (2007) Updated world map of the Köppen-Geiger climate classification. Hydrol Earth Syst Sci 11:1633-1644. https://doi.org/10.5194/hess-11-1633-2007

46. Pirhofer-Walzl K, Rasmussen J, Høgh-Jensen $\mathrm{H}$ et al (2012) Nitrogen transfer from forage legumes to nine neighbouring plants in a multi-species grassland. Plant Soil 350:71-84. https://doi.org/10.1007/s11104-011-0882-z

47. Pulido-Fernández M, Schnabel S, Lavado-Contador JF et al (2013) Soil organic matter of Iberian open woodland rangelands as influenced by vegetation cover and land management. Catena 109:13-24. https://doi.org/10.1016/j.catena.2013.05.002

48. R Core Team (2019) R: A language and environment for statistical computing

49. Robinson $D(2001) \delta^{15} \mathrm{~N}$ as an integrator of the nitrogen cycle. Trends Ecol Evol 16:153-162. https://doi.org/10.1016/S0169-5347(00)02098-X

50. Santi C, Bogusz D, Franche C (2013) Biological nitrogen fixation in non-legume plants. Ann Bot 111:743-767. https://doi.org/10.1093/aob/mct048

51. Schenk HJ, Jackson RB (2002) Rooting depths, lateral root spreads and below-ground / allometries of plants in water-limited ecosystems. J Ecol 90:480-494. https://doi.org/10.1046/j.13652745.2002.00682.x 
52. Sebastià M-T (2007) Plant guilds drive biomass response to global warming and water availability in subalpine grassland. J Appl Ecol 44:158-167. https://doi.org/10.1111/j.1365-2664.2006.01232.x

53. Sheffer E, Canham CD, Kigel J, Perevolotsky A (2015) Countervailing effects on pine and oak leaf litter decomposition in human-altered Mediterranean ecosystems. Oecologia 177:1039-1051. https://doi.org/10.1007/s00442-015-3228-3

54. Song L, Bao X, Liu X et al (2011) Nitrogen enrichment enhances the dominance of grasses over forbs in a temperate steppe ecosystem. Biogeosciences 8:2341-2350. https://doi.org/10.5194/bg-8-23412011

55. Symstad AJ (2000) A Test of the Effects of Functional Group Richness and Composition on Grassland Invasibility. Ecology 81:99-109. https://doi.org/10.1890/00129658(2000)081[0099:ATOTEO]2.0.CO;2

56. Tilman D, Lehman CL, Thomson KT (1997) Plant diversity and ecosystem productivity: Theoretical considerations. Proc Natl Acad Sci 94:1857-1861. https://doi.org/10.1073/pnas.94.5.1857

57. Unkovich $M$ (2013) Isotope discrimination provides new insight into biological nitrogen fixation. New Phytol 198:643-646. https://doi.org/10.1111/nph.12227

58. Valera-Burgos J, Díaz-Barradas MC, Zunzunegui M (2012) Effects of Pinus pinea litter on seed germination and seedling performance of three Mediterranean shrub species. Plant Growth Regul 66:285-292. https://doi.org/10.1007/s10725-011-9652-4

59. van der Merwe NJ, Medina E (1991) The canopy effect, carbon isotope ratios and foodwebs in amazonia. J Archaeol Sci 18:249-259. https://doi.org/10.1016/0305-4403(91)90064-V

60. van Diest A (1987) Plant and soil interface and intreactions. Proceedings of the International Symposium: Plant and Soil: Interfaces and Interactions. Wageningen, The Netherlands August 6-8, 1986, 1 st edn. Springer Netherlands

61. Venables WN, Ripley BD (2002) Modern Applied Statistics with S, 4th edn. Springer-Verlag, New York

62. Warembourg FR, Roumet C, Lafont F (2003) Differences in rhizosphere carbon-partitioning among plant species of different families. Plant Soil 256:347-357.

https://doi.org/10.1023/A:1026147622800

63. Weaver JE (1958) Classification of Root Systems of Forbs of Grassland and a Consideration of Their Significance. Ecology 39:393-401. https://doi.org/10.2307/1931749

64. Werner RA, Bruch BA, Brand WA (1999) ConFlo III - An -Interface for High Precision d13C and d15N Analysis with an Extended Dynamic Range. Rapid Commun Mass Spectrom 13:1237-1241

65. Yoneyama T, Matsumaru T, Usui K, Engelaar WMHG (2001) Discrimination of nitrogen isotopes during absorption of ammonium and nitrate at different nitrogen concentrations by rice (Oryza sativa L.) plants. Plant Cell Environ 24:133-139. https://doi.org/10.1046/j.1365-3040.2001.00663.x

\section{Tables}


Table 1. Linear modelling of soil $\mathrm{C}$ and $\mathrm{N}$ content (\%) as function of plot and canopy. Plot with SM-ilex as reference level, and canopy with open grassland (OG) as reference level. Estimates of the explanatory variables (Est.), standard error (SE), $t$ and $p$-value.

\begin{tabular}{|c|c|c|c|c|c|c|c|c|}
\hline & \multicolumn{4}{|c|}{ Soil C content (\%) } & \multicolumn{4}{|c|}{ Soil N content (\%) } \\
\hline & Est. & SE & $\mathrm{t}$ & $\mathbf{p}$ & Est. & SE & $\mathbf{t}$ & $\mathrm{p}$ \\
\hline (Intercept) & 2.1 & 0.4 & 5.73 & $<0.001$ & 0.18 & 0.03 & 6.77 & $<0.001$ \\
\hline Plot (DN-mixed) & -1.1 & 0.4 & -2.65 & 0.01 & -0.10 & 0.03 & -3.31 & 0.002 \\
\hline Plot (DN-suber) & -0.2 & 0.5 & -0.43 & 0.7 & -0.02 & 0.03 & -0.68 & 0.5 \\
\hline Plot (DN-pinea) & -0.8 & 0.5 & -1.73 & 0.09 & -0.09 & 0.03 & -2.63 & 0.01 \\
\hline Canopy & 1.8 & 0.3 & 6.20 & $<0.001$ & 0.11 & 0.02 & 5.39 & $<0.001$ \\
\hline \multicolumn{9}{|c|}{ Plot (DN-mixed) x canopy } \\
\hline \multicolumn{9}{|c|}{ Plot (DN-suber) x canopy } \\
\hline \multicolumn{9}{|c|}{ Plot (DN-pinea) x canopy } \\
\hline $\mathrm{R}_{\mathrm{Adj}}$ & 0.53 & & & $<0.001$ & 0.51 & & & $<0.001$ \\
\hline
\end{tabular}

Table 2. Linear modelling of C content (\%) in belowground biomass (BGB) as function of plot and canopy. Plot with SM-ilex as reference level, and canopy with open grassland (OG) as reference level. Estimates of the explanatory variables (Est.), standard error (SE), $t$ and $p$-value.

Table 3. Linear modelling of $\delta^{13} \mathrm{C}(\%)$ and $\mathrm{N}$ content (\%) in forbs as function of plot and canopy. Plot with SM-ilex as reference level, and canopy with open grassland (OG) as reference level. Estimates of the explanatory variables (Est.), standard error (SE), $t$ and $p$-value.

\section{Figures}




\begin{tabular}{|lllll|}
\hline & BGB C content (\%) \\
\hline & Est. & SE & $\mathbf{t}$ & $\mathbf{p}$ \\
\hline (Intercept) & 30 & 1 & 20.12 & $<0.001$ \\
\hline Plot (DN-mixed) & 2 & 2 & 1.03 & 0.3 \\
\hline Plot (DN-suber) & 4 & 2 & 2.04 & 0.05 \\
\hline Plot (DN-pinea) & 9 & 2 & 4.07 & $<0.001$ \\
\hline Canopy & 4 & 3 & 1.37 & 0.2 \\
\hline Plot (DN-mixed) x canopy & 2 & 3 & 0.55 & 0.6 \\
\hline Plot (DN-suber) x canopy & -1 & 3 & -0.25 & 0.8 \\
\hline Plot (DN-pinea) x canopy & -8 & 3 & -2.23 & 0.03 \\
\hline R $^{2}{ }_{\text {Adj }}$ & 0.41 & & & 0.001 \\
\hline
\end{tabular}

\begin{tabular}{|llllllllll|}
\hline & \multicolumn{3}{l}{ Forbs $\mathbf{~}^{13} \mathbf{C}(\%)$} & \multicolumn{5}{c|}{ Forbs N content (\%) } \\
& Est. & SE & $\mathbf{t}$ & $\mathbf{p}$ & Est. & SE & $\mathbf{t}$ & $\mathbf{p}$ \\
\hline (Intercept) & -28.2 & 0.2 & -154.92 & $<0.001$ & 2.2 & 0.2 & 10.70 & $<0.001$ \\
\hline Plot (DN-mixed) & -0.5 & 0.2 & -2.34 & 0.02 & -0.8 & 0.2 & -3.14 & 0.002 \\
\hline Plot (DN-suber) & -0.2 & 0.2 & -0.79 & 0.4 & -0.9 & 0.3 & -3.43 & $<0.001$ \\
\hline Plot (DN-pinea) & -0.4 & 0.2 & -1.69 & 0.09 & -0.6 & 0.3 & -2.33 & 0.02 \\
Canopy & -0.5 & 0.1 & -3.72 & $<0.001$ & 0.0 & 0.3 & 0.17 & 0.9 \\
\hline DN-mixed x canopy & & & & & 0.9 & 0.3 & 2.48 & 0.01 \\
\hline DN-suber x canopy & & & & & 0.4 & 0.4 & 1.07 & 0.3 \\
\hline DN-pinea x canopy & & & & & 0.9 & 0.4 & 2.24 & 0.03 \\
\hline$R^{2}$ Adj & 0.15 & & & $<0.001$ & 0.34 & & & $<0.001$ \\
\hline
\end{tabular}



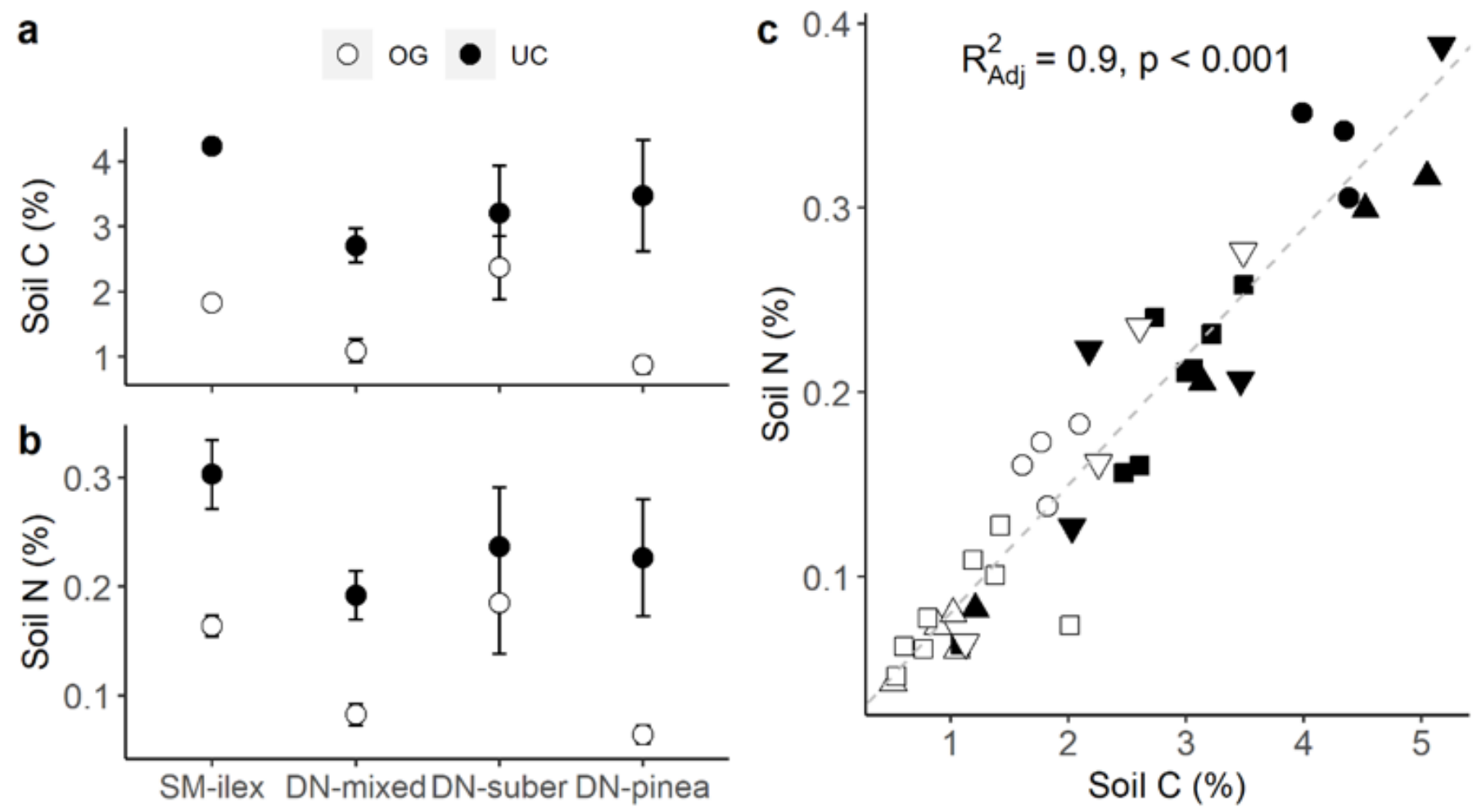

Figure 1

(a) Mean soil $\mathrm{C} \pm 1$ standard error; (b) mean soil $\mathrm{N} \pm 1$ standard error; and (c) soil $\mathrm{N}$ versus soil $\mathrm{C}$ per plot (shapes = @ $९$ SM-ilex, o $\square$ DN-mixed, $\nabla \nabla D N$ suber, $\triangle \Delta D N$ pinea), and canopy (open symbols indicate open grassland and solid symbols indicate under the canopy). 


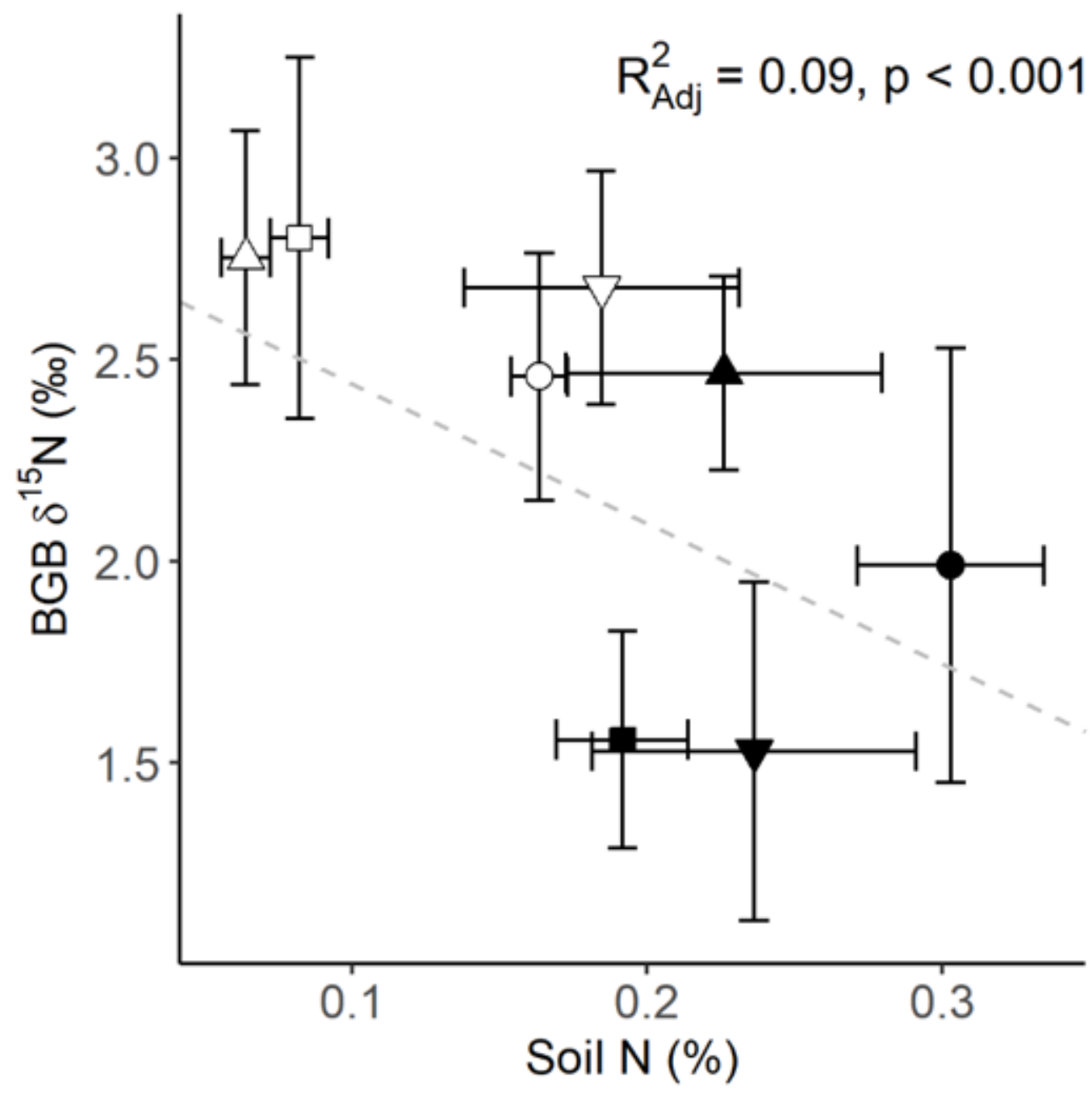

Figure 2

Relationship between belowground biomass (BGB) $\delta 15 \mathrm{~N}$ and soil N, per plot (shapes = 0 SM-ilex, o $D N$-mixed, $\nabla \nabla D N$ suber, $\triangle \triangle D N$ pinea) and canopy (open symbols indicate open grassland and solid symbols indicate under the canopy). Mean \pm 1 standard error, and linear trend line. 
O OG • UC

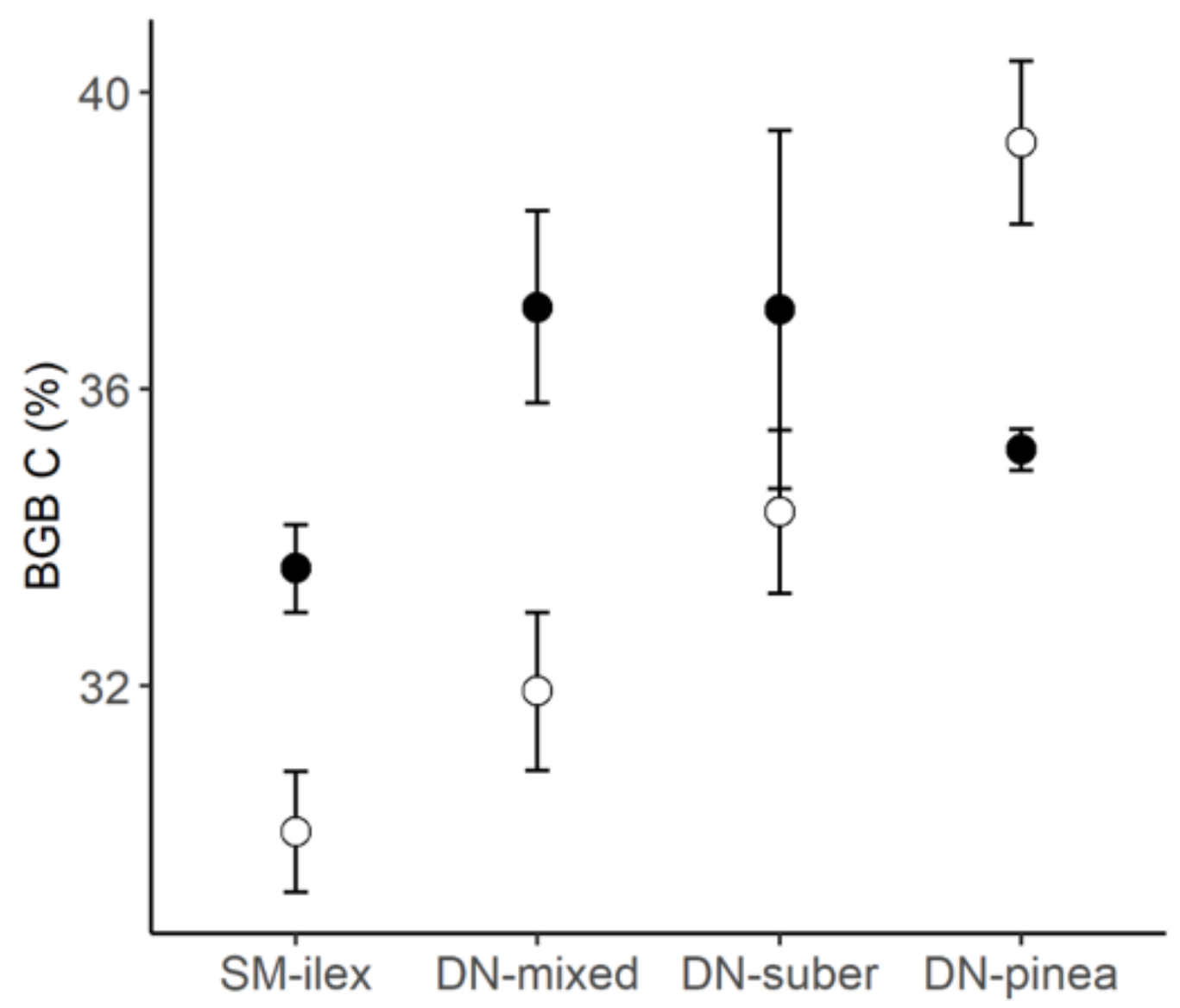

Figure 3

Mean $\mathrm{C}$ content in belowground biomass (BGB) \pm 1 standard error, per plot and canopy: open grassland (OG) and under the canopy (UC). 


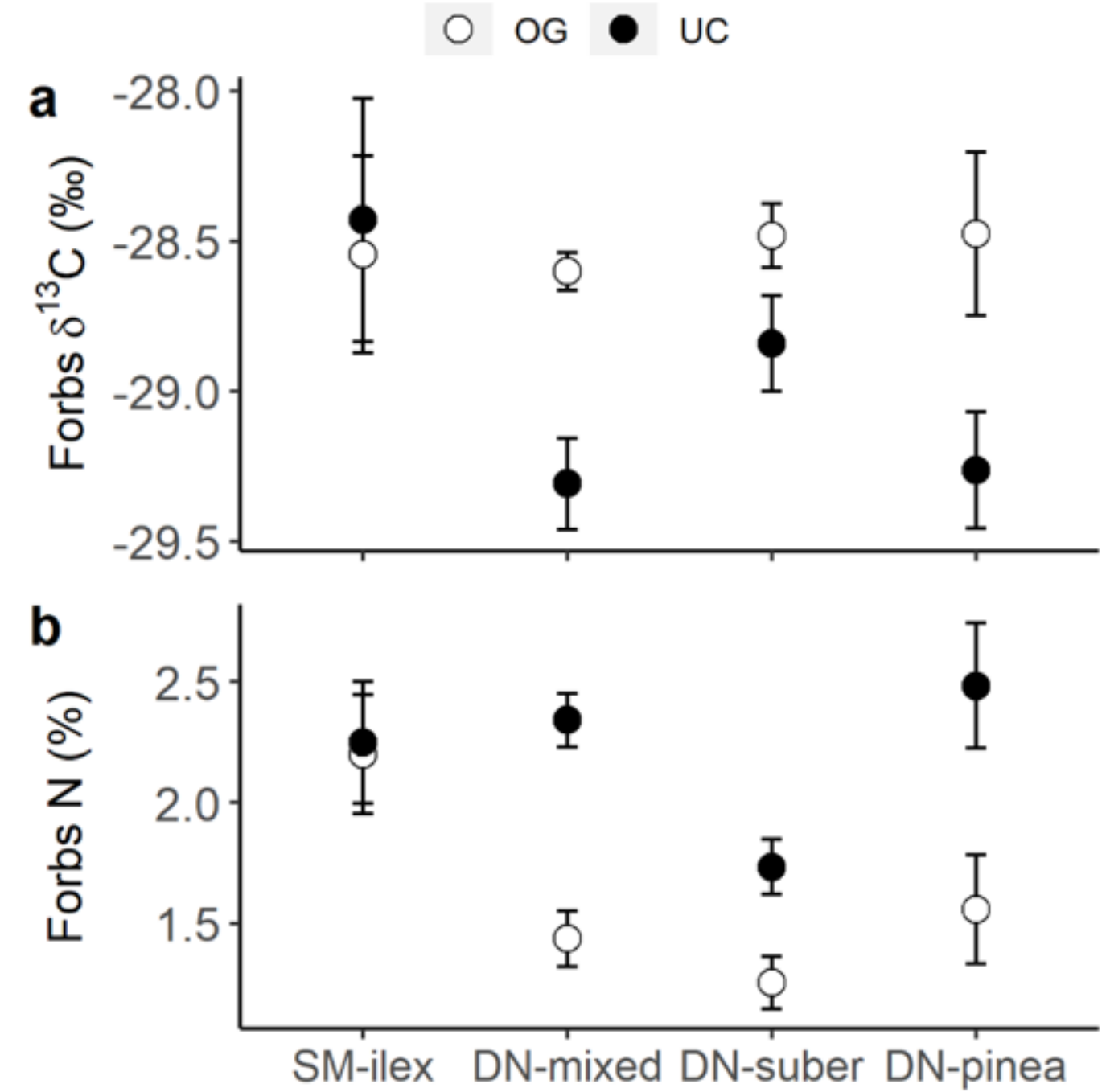

Figure 4

(a) Forbs $\delta 13 \mathrm{C}$; and (b) forbs $\mathrm{N}$ content per plot and canopy: open grassland (OG) and under the canopy (UC). Mean \pm 1 standard error. 

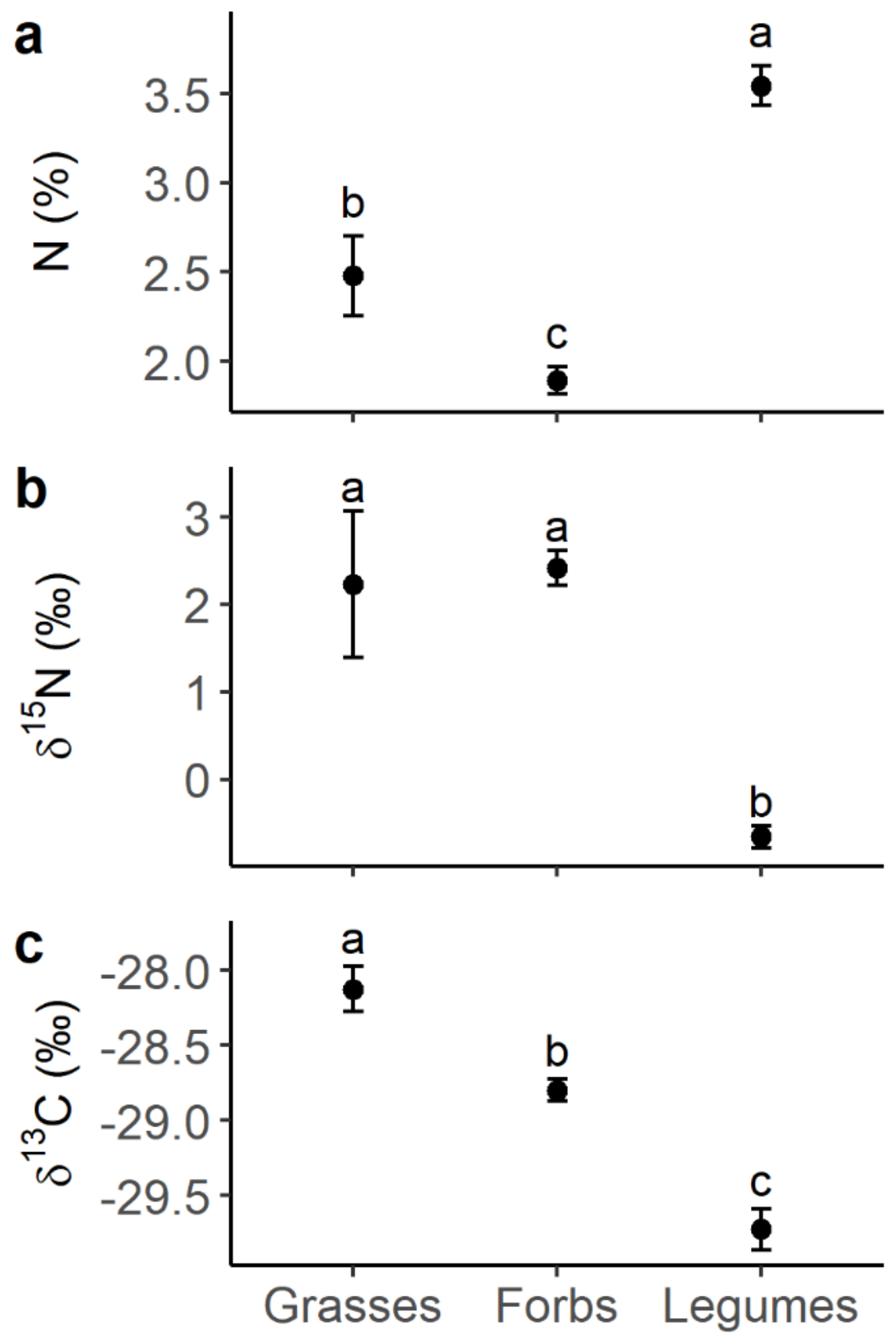

Figure 5

(a) Nitrogen content; (b) $\delta 15 \mathrm{~N}$; and (c) $\delta 13 \mathrm{C}$ in grasses, forbs, and legumes. Mean \pm 1 standard error. Letters indicate significant differences among groups $(p<0.05)$ based on Tukey post hoc tests. 

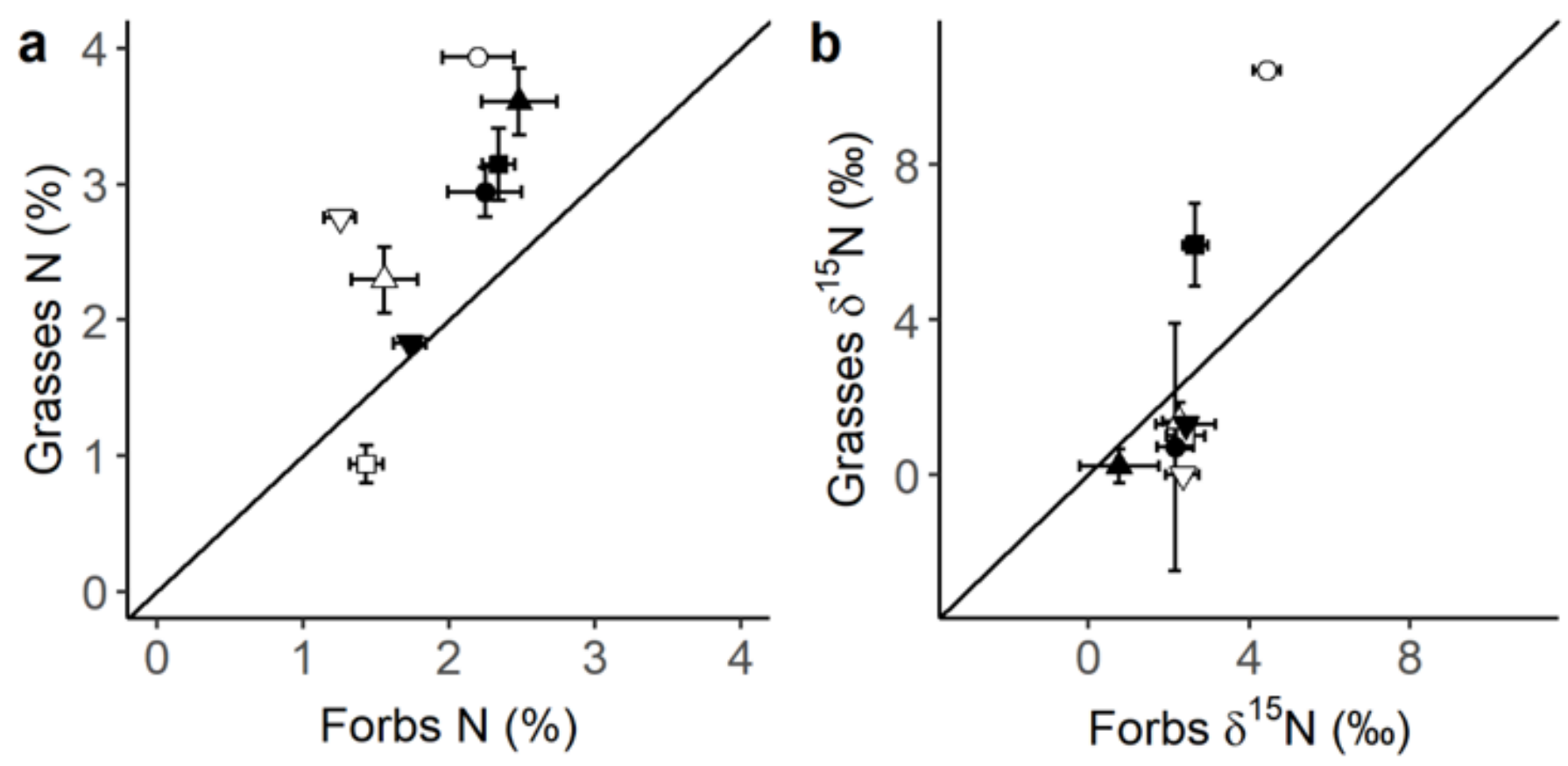

Figure 6

Relationship between (a) grasses $\mathrm{N}$ content and forbs $\mathrm{N}$ content; and (b) grasses $\delta 15 \mathrm{~N}$ and forbs $\delta 15 \mathrm{~N}$, per plot (shapes $=\bullet$ SM-ilex, o D DN-mixed, $\nabla \boldsymbol{\nabla}$ DN suber, $\triangle \boldsymbol{\Delta D N}$ pinea) and canopy (open symbols indicate open grassland, and solid symbols indicate under the canopy). Mean \pm 1 standard error. Diagonal line indicates the 1:1 relationship. 